Board of Governors of the Federal Reserve System

International Finance Discussion Papers

Number 466

May 1994

\title{
THE FEDERAL FUNDS RATE AND THE IMPLEMENTATION OF MONETARY POLICY: ESTIMATING THE FEDERAL RESERVE'S REACTION FUNCTION
}

Allan D. Brunner

NOTE: International Finance Discussion Papers are preliminary materials circulated to stimulate discussion and critical comment. References in publications to International Finance Discussion Papers (other than an acknowledgement that the writer had access to unpublished material) should be cleared with the author or authors. 


\begin{abstract}
Several recent studies have reached quite different conclusions about which variable is the best indicator of the stance of monetary policy. These differences likely reflect varying assumptions about bank and Federal Reserve behavior. This paper takes a detailed and comprehensive look at the implementation of monetary policy and the identification of monetary policy shocks. The paper first outlines a general analytical model for studying and evaluating monetary policy procedures. The model is then used to estimate both the Fed's operational policy objectives and its intermediate objectives. The results can be summarized as follows: First, monetary policy shocks over the past several years have primarily affected the federal funds rate, even during periods when the Fed was reportedly targeting reserves. In addition, the paper finds a statistically-significant liquidity effect in all periods examined, although the effect is quite small. Finally, there is statistical evidence that suggests that the Fed's intermediate objectives have not been stable over time, and these differences appear to be economically important. Taken together, these results indicate that while monetary policy shocks can be uncovered by regressing the funds rate on appropriate variables in the Fed's information set, the reaction function should be estimated over subperiods rather than over the entire 1959-1993 period.
\end{abstract}




\title{
The Federal Funds Rate and the Implementation of Monetary Policy: Estimating the Federal Reserve's Reaction Function
}

\author{
Allan D. Brunner ${ }^{1}$
}

\section{Introduction}

Over the past several years, there has been a great deal of interest in identifying monetary policy shocks and in tracing out their effects on the macroeconomy. An important element of this research involves correctly specifying the Federal Reserve reaction function, and economists have used increasingly more sophisticated reaction functions. Initially, researchers focused on intermediate targets of monetary policy, such as a monetary aggregate or a short-term capital market interest rate. Sims (1972) and Barro (1977, 1978), for example, assumed that the money supply could be controlled by the Fed and, therefore, that innovations in money represented policy shocks. By contrast, Sims (1980) concluded that the Fed targeted short-term capital market interest rates, indicating that innovations in interest rates rather than money should be interpreted as policy surprises.

Of course, the Federal Reserve cannot control its intermediate targets over short periods of time. As a result, innovations in both money and interest rates are likely to contain new information about money demand as well as information about monetary policy. This criticism has been addressed in a number of recent studies that focus on the operational targets of the Federal Reserve, such as the federal funds rate or bank reserve measures. Essentially, this line of research argues that broad monetary aggregátes or capital market interest rates are contemporaneously influenced as much by

1 The author is a staff economist in the International Finance Division. I am grateful to John Ammer, Hali Edison, Cheryl Edwards, Joe Gagnon, Christian Giles, Dale Henderson, Eric Leeper and Glenn Rudebusch, as well as seminar participants at Georgetown University and the Board of Governors, for helpful comments and suggestions on earlier versions of this paper. I would also like to thank Greg Belzer and Susan Helfrey for excellent research assistance. The views expressed in this paper are mine and do not necessarily reflect those held by the Board of Governors or any member of its staff. I am also responsible for any and all errors. 
money demand shocks as by money supply shocks. As in the earlier studies, however, there has not been a general consensus on which short-run variable best indicates the stance of monetary policy. Christiano and Eichenbaum (1992) and Strongin (1992) have advocated reserve-based measures, while Bernanke and Blinder (1992) have argued in favor of the federal funds rate. More recently Gordon and Leeper (1993) have considered the possibility that innovations in both the funds rate and bank reserves could contain new information about monetary policy.

These studies differ in several ways that could account for their respective conclusions. First, although each uses a vector-autoregressive (VAR) approach, their implementations of that methodology are quite different. For example, they do not use the same conditioning information to identify innovations. That is, they make different assumptions about the Federal Reserve's information set. Christiano and Eichenbaum and Gordon and Leeper obtained VAR innovations in reserves market variables by regressing those variables on lags of both reserves market variables (the federal funds rate, nonborrowed reserves, etc.) and macroeconomic variables (output, prices, etc.). By contrast, Strongin used only reserves market variables as conditioning information.

These studies also impose different assumptions in order to identify structural shocks. In particular, they do not make the same assumptions about the determinants of the demand for and the supply of bank reserves. Christiano and Eichenbaum and Strongin, for example, assume that the supply of reserves is not influenced by changes in contemporaneous interest rates -- an assumption that is violated during those periods when the Fed was reportedly targeting the federal funds rate. In addition, Strongin assumes that innovations in total reserves are due entirely to demand shocks. This assumption is also quite strong, since it implies that the demand for excess (and thus total) reserves is insensitive to contemporaneous interest rates. This assumption seems implausible given empirical observations that banks hold less excess reserves in the face of high interest rates. ${ }^{2}$ By contrast,

\footnotetext{
2 See, for example, Brunner and Lown (1993a).
} 
although Bernanke and Blinder and Gordon and Leeper allow both the supply of and demand for reserves to depend on contemporaneous interest rates, they assume that only the federal funds rate is important in determining an equilibrium in the reserves market, ignoring the possible role of the discount rate.

Second, these studies do not evaluate the importance of supply and demand shocks in the same ways. The restrictions made by Christiano and Eichenbaum and Strongin are imposed and are not tested explicitly. Bernanke and Blinder rely exclusively on the size and significance of regression coefficients to determine which innovations (in reserves or in interest rates) best indicate policy shocks. By contrast, Gordon and Leeper examine the contribution of policy shocks to the variance of innovations in both reserves and the federal funds rate. This approach is more appropriate, since statistical significance of a coefficient does not necessarily imply an important role in transmitting policy shocks to reserves market variables.

Finally, these studies do not focus on the same time periods. While Strongin examines the 1959-1991 period and various subperiods, Bernanke and Blinder focus primarily on pre-1979 policy procedures, and Gordon and Leeper examine only the 1971-1979 and 1982-1992 periods. As a consequence, it is somewhat difficult to compare their empirical results.

In light of these differences, this paper takes a detailed and comprehensive look at the implementation of monetary policy and the identification of monetary policy shocks. The first goal of the paper is to outline a general analytical model that highlights the implementation of monetary policy and that provides a basis for subsequent statistical analysis. This model is similar to those used by Brunner (1993) and Brunner and Lown (1993a, 1993b) to study the effects of monetary policy procedures. The model is less restrictive and more realistic than those used in previous studies, and it provides the opportunity to clarify many outstanding issues regarding the appropriate way to identify monetary policy shocks. 
The analytical model focuses on the implementation of monetary policy as a multiple-objective process, as the Fed reacts to both past and contemporaneous information depending on its intermediate and short-run objectives. Since the Federal Reserve cannot directly achieve its ultimate policy goals, it relies on intermediate targets and indicators. Over the past several years, the Fed has primarily used monetary aggregates as intermediate targets, supplemented with other indicators of economic activity and price developments. In addition, the Federal Reserve sets short-term (operational) targets, since it cannot effectively achieve its intermediate targets over relatively short periods of time. As Meulendyke (1990) has noted, operational targets "have, in a sense, come full circle since the 1950s: the FOMC initially targeted free reserves and then shifted to federal funds rates, to nonborrowed reserves, and more recently to borrowed reserves, a measure similar in many ways to free reserves."

The second goal of the paper is use the model to identify the Fed's policy objectives. As will be discussed shortly, the Fed's short-term objective can be determined by estimating the slope of the nonborrowed reserve supply curve for various periods, which indicates the Fed's tolerance for contemporaneous changes in the federal funds rate. In contrast to some previous studies, an important conclusion of this paper is that innovations in the federal funds rate were almost entirely due to monetary policy shocks, even during periods when the Fed was reportedly targeting reserves. Indeed, although the slope of the supply schedule increased sharply during the 1979-82 period, unexpected changes in the supply of reserves during that period were primarily reflected in changes in the funds rate rather than in the quantity of reserves. On balance, depending on the time period, between 85 and 100 percent of the variance in the funds rate can be attributed to policy shocks. In addition, the paper finds a statistically-significant liquidity effect in all periods examined, although the effect $\mathrm{i}$ is quite small. This result contrasts sharply with several other studies, although it is consistent with those that have assumed that innovations in the federal funds rate provide the best measure of monetary policy shocks. 
This paper also examines the stability of the Fed's intermediate policy objectives. There are several reasons to believe that the Fed's intermediate objectives have not been constant over time. The Fed's emphasis on various intermediate targets and indicators has changed over time as the FOMC became dissatisfied with the performance of particular targets or indicators. In addition, the composition of the FOMC itself has also changed, likely resulting in a shifting of the weights placed on these intermediate objectives by the FOMC. Statistical tests indicate that the Fed's intermediate policy objectives have not been constant over time, and these differences appear to be economically important.

Taken together, these results indicate that monetary policy shocks can be uncovered by regressing the federal funds rate on appropriate variables in the Fed's information set. However, there is also evidence to suggest that the Fed's reaction function should be estimated over selected subperiods rather than over the entire 1959-1993 period.

The remainder of the paper is organized as follows. The analytical model is presented in

section II, and the corresponding statistical model is outlined in Section III. The results of estimating and identifying the Fed's operational and intermediate policy objectives are presented and discussed in Sections IV and V, respectively. Section VI provides concluding remarks.

\section{An Analytical Framework}

This section of the paper outlines an analytical model of the macroeconomy with a special emphasis on the monetary policy process. In particular, the model describes several behavioral relationships in the reserves market, and it outlines the links between reserves market variables -- the federal funds rate, the discount rate, and bank reserves -- and general macroeconomic variables -- such as output, prices and monetary aggregates. This model will be used in the next section to motivate a structural statistical model that is the basis for subsequent econometric work. The analytical model is similar to those used by Brunner (1993) and Brunner and Lown (1993a, 1993b) to study the reserves 
market, and it is a generalization of the framework used by McCallam (1990) to examine the linkages between intermediate targets and indicators and the ultimate objectives of monetary policy. ${ }^{3}$

The Macroeconomy. Let $\mathrm{X}_{\mathrm{t}}$ denote an $\mathrm{Nx} 1$ vector of economic variables that summarize the state of the macroeconomy at time $t$. The contents of $X_{t}$ will be described later, but it is assumed that $\mathrm{X}_{\mathrm{t}}$ depends on contemporaneous values of itself and lagged (but not contemporaneous) values of reserve market variables. Ignoring the role of lagged information, the time series behavior of $X_{t}$ can be written as follows:

$$
\Gamma_{0} \cdot X_{t}=\mu_{t}
$$

where $\Gamma_{0}$ denotes an $\mathrm{NxN}$ matrix summarizing the contemporaneous relationships between elements of $X_{t}$, and $\mu_{t}$ represents an Nx1 vector of structural shocks to $X_{t}$.

The Demand for Reserves. The market for bank reserves is linked to the macroeconomy $\left(\mathrm{X}_{\mathrm{t}}\right)$ in several ways, but the primary link is through reserve requirements. Again ignoring lagged information, required reserve balances are assumed to be calculated as follows:

$$
R R_{t}=\alpha \cdot X_{t}+\eta_{t}
$$

where $R R_{t}$ is the aggregate quantity of required reserves and $\eta_{t}$ denotes an unexpected change in required reserves. In addition to holding reserves to satisfy reserve requirements, banks hold "excess" reserves in order to avoid reserve deficiencies (when total reserves fall below required reserves) and reserve overdrafts (when total reserves fall below zero), both of which may occur as a result of unexpected reserve outflows (i.e., due either to $\mu_{t}$ or $\eta_{t}$ ). The demand for total reserves can be written as:

3 In order to make the exposition more succinct, the following discussion focuses primarily on contemporaneous relationships, ignoring the role of lagged information when possible. 


$$
T R_{t}^{D}=R R_{t}+E R_{t}^{D}
$$

where $\mathrm{TR}^{\mathrm{L}}{ }_{\mathrm{t}}$ and $\mathrm{ER}^{\mathrm{D}}{ }_{\mathrm{t}}$ represent the desired quantities of total and excess reserves, respectively.

Banks can obtain reserves from several sources. First, a bank can borrow reserves from the discount window at its Federal Reserve Bank, and the cost of "borrowed" reserves is the discount rate. In addition, banks can obtain "nonborrowed" reserves, which are supplied by the Federal Reserve through open market operations. These funds can be secured either directly from the Fed or indirectly from other banks in the federal funds market. It is assumed here that both types of transactions are arranged using the federal funds rate. The demand for total reserves by source of funds can be written as follows:

$$
T R_{t}^{D}=B R_{t}^{D}+N B R_{t}^{D}
$$

where $\mathrm{BR}^{\mathrm{D}}{ }_{\mathrm{t}}$ and $\mathrm{NBR}^{\mathrm{D}}{ }_{t}$ represent the desired quantities of borrowed and nonborrowed reserves, respectively.

If banks want to hold excess reserves then, they must weigh the costs of borrowed reserves (the discount rate) against the costs of nonborrowed reserves (the federal funds rate); an increase, for example, in the discount rate will likely induce a shift away from borrowed reserves toward nonborrowed reserves. In addition, if borrowed and nonborrowed reserves are not perfect substitutes, there will be an overall reduction in the holdings of excess and total reserves. ${ }^{4}$ It is also expected that banks will want to adjust their holdings of excess and total reserves according to the level of required reserves or the level of economic activity $\left(X_{t}\right)$. Continuing to ignore lagged values, these assumptions imply a derived-demand curve for excess reserves (and for total reserves) that has the

4 See Goodfriend (1983) for a discussion of why borrowed and nonborrowed reserves are unlikely to be perfect substitutes. 
following form:

$$
E R_{t}^{D}=\beta_{1}^{*} \cdot R_{f, t}+\beta_{2}^{*} \cdot R_{d, t}+\beta_{3}^{*} \cdot R_{t}+\beta_{4}^{*} \cdot X_{t}+v_{t}
$$

where $R_{f, t}$ and $R_{d, t}$ denote the federal funds rate and the discount rate, respectively, and $v_{t}$ is an unexpected shock to the demand for excess reserves. ${ }^{5}$ The relationships in equations (3) through (5) also imply derived-demand curves for borrowed and nonborrowed reserves, respectively:

$$
\begin{aligned}
B R_{t}^{D} & =\beta_{1}^{* *} \cdot R_{f, t}+\beta_{2}^{* *} \cdot R_{d, t}+\beta_{3}^{* *} \cdot R R_{t}+\beta_{4}^{* *} \cdot X_{t}+\delta \cdot v_{t} \\
N B R_{t}^{D} & =\beta_{1} \cdot R_{f, t}+\beta_{2} \cdot R_{d, t}+\beta_{3} \cdot R R_{t}+\beta_{4} \cdot X_{t}+(1-\delta) \cdot v_{t} \\
& =\beta_{1} \cdot R_{f, t}+\beta_{2} \cdot R_{d, t}+\beta_{3} \cdot R R_{t}+\beta_{4} \cdot X_{t}+\lambda_{t}
\end{aligned}
$$

where $\delta$ equals the portion of the shock to excess reserves $\left(v_{t}\right)$ that shows up in the demand for borrowed reserves (rather than nonborrowed reserves), and $\lambda_{t}=(1-\delta) \cdot v_{t}$, the magnitude of the shock that affects the demand for nonborrowed reserves. ${ }^{6}$

The Supply of Reserves. The Federal Reserve has three primary instruments for affecting the supply of reserves -- reserve requirement ratios, the discount rate, and open market operations. Reserve requirement ratios are imbedded implicitly in equation (2), and changes in those ratios are assumed to be infrequent and relatively less important compared with other instruments. Changes in the discount rate at Federal Reserve District Banks must be approved by the Board of Governors, and it is assumed that the Board allows these changes based on other short-term interest rates, proxied here by the federal funds rate:

5 See Brunner (1993) for a derivation of equation (4) in an optimizing framework.

6 The assumption of just one type of demand shock to total reserves $\left(v_{t}\right)$ ignores the possibility, for example, that the nonborrowed reserve or the borrowed reserve functions themselves are not perfectly stable. For a theoretical analysis of this possibility, see Thorton (1988). 


$$
R_{d, t}=\pi \cdot R_{f, t}+\omega_{t}
$$

where $\omega_{\mathrm{t}}$ is an unexpected change in the discount rate.

In its efforts to influence conditions in the reserves market over short periods of time, the Federal Reserve also sets operational (short-term) objectives for the federal funds rate and for each reserve aggregate -- total, excess, borrowed and nonborrowed reserves. It is important to recognize, given the pleceding set of assumptions, that setting an objective for any one of these variables determines the objectives for the others. For example, suppose the Fed chooses an intended level for nonborrowed reserves at the beginning of period $\mathrm{t}$ based on an intermediate policy rule that links this target variable to available information about the macroeconomy:

$$
N B R_{t}^{T}=\tau \cdot X_{t-1}
$$

where $\mathrm{NBR}^{\mathrm{T}}{ }_{\mathrm{t}}$ denotes the intended level of nonborrowed reserves.

Given the intended level of nonborrowed reserves $\left(\mathrm{NBR}_{t}^{\mathrm{T}}\right)$ and forecasts of economic conditions and of required reserves -- using equations (1) and (2) -- equations (7) and (8) can be used to calculate the corresponding expected trading level for the federal funds rate $\left(R_{f, t}^{T}\right)$. That is, assuming that the Fed has complete understanding of the underlying determinants of reserve demand:

$$
R_{f, t}^{T}=E\left[R_{f, t} \mid I_{t-1}\right]
$$

where $I_{t-1}$ contains all information available to the Fed at the beginning of period $t$, including the target level for nonborrowed reserves. Similarly, equations (3) through (6) can be used to derive expected levels for the remaining reserve aggregates that are consistent with the nonborrowed reserve 
objective. $^{7}$

Alternatively, the Fed could choose a federal funds rate target in each period based on a policy rule similar to equation (9):

$$
R_{f, t}^{T}=\tau^{*} \cdot X_{t-1}
$$

where $\mathrm{R}_{f, t}^{\mathrm{T}}$ denotes the intended level of the funds rate. Again, given the federal funds rate target and forecasts of economic activity and required reserves, equations (3) through (8) imply expected levels for all reserve aggregates.

Although the Fed cannot observe developments in most reserve aggregates during a period, it can observe the contemporaneous federal funds rate. As a consequence, the Fed's operational policy

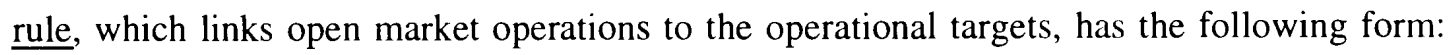

$$
O M O_{t}=N B R_{t}^{T}-N B R_{t-1}+\gamma \cdot\left(R_{f, t}-R_{f, t}^{T}\right)+\epsilon_{t}
$$

where $\mathrm{OMO}_{\mathrm{t}}$ denotes the quantity of open market operations during period $t$, and $\varepsilon_{\mathrm{t}}$ represents the unexpected portion of the operation during period t. In addition to reflecting unexpected changes in policy, $\varepsilon_{\mathrm{t}}$ also contains unanticipated reserve factors that are outside the Fed's control, such as the Treasury's balance at the Fed, reserve float, or the activities of foreign central banks.

Whether the Fed pursues a pure reserves-targeting policy, a pure funds-rate-targeting policy, or a combination policy, depends on the value of $\gamma$ in equation (12). If $\gamma=0$, the Fed supplies only enough reserves to reach the targeted level of nonborrowed reserves and ignores whether federal funds are trading away from their expected level. If $>0$, the Fed adjusts its supply of reserves, either supplying additional reserves when funds are trading on the high side of expectations or supplying less

7 Similar rules could be used that are based on other reserve aggregates. However, given the assumptions made and assuming further that $0<\delta<1$, these rules will have identical effects as a nonborrowed reserve target. See footnote 5 for another approach. 
when the funds rate is lower than expected. At the extreme, $(\gamma=\infty)$, the Fed essentially stands ready to buy or sell reserves at the targeted federal funds rate.

The supply of nonborrowed reserves during period t then consists of the amount of reserves available from the previous period $\left(\mathrm{NBR}_{\mathrm{t}-1}\right)$ plus the amount added during the period:

$$
\begin{aligned}
N B R_{t}^{S} & =N B R_{t-1}+O M O_{t} \\
& =N B R_{t}^{T}+\gamma \cdot\left(R_{f, t}-R_{f, t}^{T}\right)+\epsilon_{t}
\end{aligned}
$$

where $\mathrm{NBR}^{S}{ }_{t}$ is the aggregate supply of reserves at time t. Finally, using i) equation (12), ii) either equation (8) or (9), and iii) the expected trading level for all other variables; the supply curve for nonborrowed reserves can be written as follows:

$$
N B R_{t}^{S}=\gamma \cdot R_{f, t}+\tau^{* *} \cdot X_{t-1}+\epsilon_{t}
$$

Impcrtantly, the specification of the Fed's reaction function in equation (14) contains information both about the Fed's operational objectives $(\gamma)$ and about its intermediate objectives $\left(\tau^{* *}\right)$. It also highlights the fact that if these objectives are inappropriately specified, then the monetary policy shocks $\left(\varepsilon_{\mathrm{t}}\right)$ will also be incorrectly identified. Accordingly, the goal in the following sections is to identify the Fed's policy objectives for several subperiods from 1959-1993. Section IV will focus on estimating $\gamma$, which will identify the Fed's operational objectives. Section $\mathrm{V}$ will then focus on determining whether the Fed's intermediate objectives -- those variables for which $\tau^{* *}$ are significantly different from zero -- have been stable over time.

\section{The Statistical Model}

Before turning to estimating the Fed's reaction function, this section briefly outlines the statistical model that will be used in subsequent sections. There are several ways to estimate the behavioral relationship described in equation (14). One approach is use an over-identified system of 
structural equations that includes the reaction function. Feinman (1993), for example, estimated an operational rule similar to equation (12) using single-equation methods. Brunner and Lown (1.993a) used maximum-likelihood methods to estimate a three-equation system of the reserves market. which included a rule similar to the one in equation (14). Similarly, Anderson and Rasche (1982) and Tinsely et al. (1982) specified and estimated a more complicated structural model that included the interaction between the reserves market and various other short-term markets.

An alternative approach is to use a vector autoregressive (VAR) model -- a weakly-identified system of equations -- to study the Fed's reaction function. The primary advantage of the VAR methodology is that a minimum number of assumptions are made about the underlying structural relationships. The biggest disadvantage of this approach, however, is that a large number of degrees of freedom are used to estimate the lags of the system variables.

The analytical model described in the previous section can easily be used to construct a VAR model of the macroeconomy that has an emphasis on the reserves market and the implementation of monetary policy. First, suppose that the structural VAR model can be written as follows:

$$
A_{0} \cdot Z_{t}=A_{1} \cdot Z_{t-1}+A_{2} \cdot Z_{t-2}+\ldots+e_{t}
$$

where $Z_{t}$ denotes a vector containing the variables of interest -- $\left[R_{f, t} R_{d, t} N_{B R} R_{t} X_{t}\right]^{\prime} ; e_{\text {; }}$ represents a vector of structural shocks -- $\left[\varepsilon_{\mathrm{t}} \omega_{\mathrm{t}} \lambda_{\mathrm{t}} \eta_{\mathrm{t}} \mu_{\mathrm{t}}\right]^{\prime} ;$ and $\operatorname{Var}\left(\mathrm{e}_{\mathrm{t}}\right)=\Omega$, a diagonal matrix.

Second, the structural relationships can be identified by placing a sufficient number of zerorestrictions on $A_{0}$, which summarizes the contemporaneous relationships between elements of $Z_{t}$. Specifically, equations (14), (8), (7), (2), and (1) from the previous section can be used to identify $\mathrm{A}_{0}$ as follows: 


$$
\left[\begin{array}{ccccc}
1 & 0 & -\rho & 0 & 0 \\
-\pi & 1 & 0 & 0 & 0 \\
-\beta_{1} & -\beta_{2} & 1 & -\beta_{3} & -\beta_{4} \\
0 & 0 & 0 & 1 & -\alpha \\
0 & 0 & 0 & 0 & \Gamma_{0}
\end{array}\right] .
$$

Note that the nonborrowed reserves supply curve (the first equation in the VAR model) has been renormalized on the federal funds rate so that $\rho=1 / \gamma$.

Finally, the structural parameters of the model can be estimated using a two-step procedure described by Bernanke (1986) and Sims (1986). In the first stage of the procedure, the reduced-form representation of the VAR is estimated using OLS; let the reduced-form model be written as:

$$
Z_{t}=B_{1} \cdot Z_{t-1}+B_{2} \cdot Z_{t-2}+\ldots+u_{t}
$$

where $\operatorname{Var}\left(\perp_{\mathrm{t}}\right)=\Sigma$, a non-diagonal matrix. In the second stage of the procedure, the structural model is equated with the reduced-form model, yielding the following relationship between the structural shocks and the reduced-form innovations:

$$
A_{0} \cdot u_{t}=e_{t}
$$

The relationship in equation (18) implies that the elements of $A_{0}$ and $\Omega$ can be calculated using the first-stage estimates of $\Sigma$ and the following relationship:

$$
A_{0} \cdot \Sigma \cdot A_{0}^{\prime}=\Omega
$$

Similarly, tive elements of $A_{i}$ can be calculated by noting that $A_{i}=A_{0} \cdot B_{i}$.

The: next two sections of the paper use the structural VAR model in equation (15) to estimate and examine both elements of the Fed's reaction function and monetary policy shocks $\left(\varepsilon_{\mathrm{t}}\right)$. 


\section{The Fed's Operational Objectives}

The paper now turns to estimating the Federal Reserve's policy objectives using the VAR model described in the previous sections. In particular, this section focuses on identifying the Federal Reserve's operational objectives. As discussed earlier, this is equivalent to estimating the slcpe of the nonborrowed reserves supply equation ( $\rho$ ) for each individual subperiod: If $\rho=0$, then the Fed must be targeting the federal funds rate in that period. Alternatively, if $\rho=\infty$, then the Fed is pursuing a nonborrowed reserve target; and $0<\rho<\infty$ would indicate a combination policy.

In order to determine the Fed's operational objectives, parameter estimates were exarnined for several subperiods, which correspond to the monetary policy regimes identified by Meulendyke (1990). The operational and intermediate targets during these regimes are summarized in Table 1, and they are discussed in more detail in Appendix A. These periods were examined using two specifications of the VAR model and using both monthly and weekly data. The first VAR model assumes that the list of macroeconomic variables $\left(\mathrm{X}_{\mathrm{t}}\right)$ contains only $\mathrm{M} 2$. This is a reasonable assumption, since the FOMC has used a monetary aggregate as an intermediate target for most of the years examined in th is study (1959 to 1993). This version of the model is comparable to the models used by Bernanke and Blinder and by Strongin to study the reserves market, although it places fewer restrictions on behavioral relationships in the reserves market than the models used in the previous studies. In addition, this specification of the model permits the use of weekly data, which are readily available for mcnetary aggregates and reserve market variables but are not readily available for broader measures of economic activity, such as output, prices, and unemployment.

While the Fed has primarily used a monetary aggregate as an intermediate target, it has also looked to other variables as leading indicators of economic activity and price developments. Accordingly, the second VAR model assumes that $\mathrm{X}_{\mathrm{t}}$ contains industrial production $(\mathrm{Y})$, the consumer price index $(\mathrm{P})$, and the unemployment rate $(\mathrm{U})$, as well as M2. This version of the model is 
comparable to those models used by Christiano and Eichenbaum, Bernanke and Blinder, and Gordon and Leeper to study the effects of monetary supply shocks on the macroeconomy, although it models the implementation of monetary policy in somewhat more detail. This model is estimated using only monthly diata.

\section{A. Reserves Market Model}

The first specification of the VAR model assumes that M2 is the only intermediate target. Consequertly, $Z_{t}$ denotes a $5 \times 1$ vector containing the variables of interest $-R_{f}, R_{d}, N B R$, $R R$ and M2. Following the usual VAR conventions, quantity variables are expressed in logs, and interest rates are expressed in levels. ${ }^{8}$ As described in the previous section, the VAR innovations $\left(u_{t}\right)$ were obtained by regressing each variable on lags of all variables. ${ }^{9}$ The innovations were then decomposed into structural shocks $\left(e_{t}\right)$ using equation (18), where $A_{0}$ was defined as follows:

$$
\left[\begin{array}{ccccc}
1 & 0 & -\rho & 0 & 0 \\
-\pi & 1 & 0 & 0 & 0 \\
-\beta_{1} & -\beta_{2} & 1 & -\beta_{3} & -\beta_{4} \\
0 & 0 & 0 & 1 & -\alpha \\
0 & 0 & 0 & 0 & 1
\end{array}\right] \cdot\left[\begin{array}{c}
r_{f, t} \\
r_{d, t} \\
n b r_{t} \\
r_{t} \\
m_{t}
\end{array}\right]=\left[\begin{array}{c}
\epsilon_{t} \\
\omega_{t} \\
\lambda_{t} \\
\eta_{t} \\
\mu_{t}
\end{array}\right]
$$

and where small letters denote innovations in $R_{f, t}, R_{d, t}, \log N B R_{t}, \log R R_{t}$ and $\log M 2_{t}$, respectively. Note that innovations in M2 are predetermined with respect to the reserves market variables, and the "structural" shocks to $\mathrm{M} 2 \mathrm{t}_{\mathrm{t}}\left(\mu_{\mathrm{t}}\right)$ should be considered as amalgamations of money demand shocks, other aggregate demand shocks, and aggregate supply shocks.

8 Other specifications of these variables were tried -- including first differences and ratios to total reserves -- with qualitatively-similar results.

9 For the VAR models in this paper, twelve months of lags were used for the full sample, three months of lags were used for the 1979-82 period, and six months of lags were used for all other subperiods. 
Similar VAR models have been used by Bernanke and Blinder (1992) and by Strongin (1992). As previously discussed, however, there are a few drawbacks to their respective approaches. Strongin, for example, imposes the restriction that the supply of reserves is insensitive to changes in the federal funds rate $(\rho=\infty)$, which is equivalent to assuming that the Fed has always pursued a reserves target. In addition, Strongin ignores the possible role of the discount rate in affecting reserve availability $\left(\beta_{2}=0\right)$. While Bernanke and Blinder allow the supply of nonborrowed reserves to be sensitive to the federal funds rate, they also ignore the role of the discount rate. As will be discussed shortly, these assumptions can generally be statistically rejected for most episodes over the 1959-1993 period. Finally, Bernanke and Blinder limit their analysis almost exclusively to the pre-1979 period, which ignores two important episodes in the history of operational procedures at the Federal Reserve -- the 1979-82 period, when the Fed actively pursued a reserves target, and the 1982-present period, when the Fed began shifting toward the funds rate as its operational target.

Using Monthly Data. The VAR model of the reserves market was estimated using monthly data from January 1959 to June 1993, with the sample split into four episodes consistent with the monetary regimes identified by Meulendyke (1990). The parameter estimates for this version of the model are shown in the upper panel of Table $2 .{ }^{10}$ There are several interesting features of these estimates. First, the parameter estimates for $\rho$ in the pre-1979 episodes are fairly consistent with the estimates obtained by Bernanke and Blinder: The slope coefficients are insignificantly different from zero for the 1959-1969 and 1970-1979 episodes, indicating that the supply curve was fairly flat. By contrast, the slope increases dramatically in the 1979-1982 period, and the coefficient is significantly different from zero. In the 1982-1993 period, when the Fed started to shift away from targeting

10 The over-identifying restrictions are rejected in some periods, reflecting the model's inability to capture a contemporaneous correlation between M2 and the interest rates in those periods. I: seems unlikely that M2 responds to within-the-month movements in interest rates, but rather that both variables are responding to a variable not included in the model. 
reserve measures, the slope coefficient returns to pre-1979 levels and is insignificantly different from zero at conventional significance levels. Importantly, however, these estimates are inconsistent with the assumption made by Strongin, that the nonborrowed reserves supply function is perfectly inelastic with respect to the federal funds rate. In fact, they are more consistent with the supply function being perfectly elastic with respect to the funds rate.

Second, it is interesting to note that the estimate of $\beta_{1}$, the slope of the demand curve for nonborrowed reserves with respect to the funds rate, is negative and significantly different from zero in each time period. This contrasts sharply with several recent studies -- reviewed in Leeper and Gordon (1992) -- where the observed "liquidity effect" was often insignificant and sometimes positive. This result is consistent, however, with those studies that assumed that the federal funds rate is the best indicator of the stance of monetary policy.

Finally, it is interesting to note that the role of the discount rate (as indicated by estimates of $\beta_{2}$ ) appears to be important in most of the time periods examined, indicating that nonborrowed reserves are not perfect substitutes for borrowed reserves and that the relationship between the funds rate and the discount rate is an important determinant in the demand for reserves. This result is also inconsistent with an assumption made both by Bernanke and Blinder and by Strongin.

As previously mentioned, statistical significance of coefficients do not necessarily imply that a relationship is economically important. The bottom panel of Table 2 details the share of the variance of innovations in both nonborrowed reserves and the federal funds rate that can be attributed to monetary policy shocks $\left(\varepsilon_{\mathrm{t}}\right.$ and $\left.\omega_{\mathrm{t}}\right)$. Importantly, although the slope of the supply curve for nonborrowed reserves increased sharply in the $1979-1982$ period, the portion of the variance of nonborrowed reserves due to policy shocks increased to only 7 percent, while the share of the variance of the funds rate due to policy shocks fell to just 86 percent. In other words, although the coefficient is statistically significant in that period, it does not appear to be economically important. 
Using Weekly Data. The same approach was applied to weekly data for the same episodes. The results are summarized in Tables 3 and 4, and they are qualitatively similar to those obtained using monthly data. As shown in Table 3, although the parameter estimates of $\rho$ are generally somewhat larger and are in some cases significant from zero, the contribution of policy shock; to the variance of innovations in nonborrowed reserves is still nearly zero. In particular, the estimate for the 1979-1982 is still large and significant from zero; but, as before, the contribution of policy shocks to the variance of nonborrowed reserves for this subperiod is quite low. Indeed, as with the monthly data, the share due to policy shocks in that period is not much different than for other periods where the share is expected to be small.

As discussed by Meulendyke (1990) and Brunner and Lown (1993a), the 1982-1993 period was witness to a shift from targeting reserve measures towards targeting the federal funds rate. Table 4 explores whether this shift can be detected using weekly data, and the answer is "yes." As the table clearly shows, the slope coefficient for the supply curve dropped over this period and is quite small and insignificant from zero in the $1988-1993$ period.

\section{B. Macroeconomic Model}

While M2 has been the Fed's primary intermediate target, the Fed has also relied on other economic indicators. The remainder of this section considers a more general specification of the VAR model, where $Z_{t}$ now denotes an $8 \times 1$ vector containing the five variables used in the previous model,

plus $\log Y_{t}, U_{t}$, and $\log P_{t}$. As before, the VAR innovations were obtained by regressing each variable on lags of all variables. The innovations were then decomposed as follows: 


$$
\left[\begin{array}{cccccccc}
1 & 0 & -\rho & 0 & 0 & 0 & 0 & 0 \\
-\pi & 1 & 0 & 0 & 0 & 0 & 0 & 0 \\
-\beta_{1} & -\beta_{2} & 1 & -\beta_{3} & -\beta_{4} & 0 & 0 & 0 \\
0 & 0 & 0 & 1 & -\alpha & 0 & 0 & 0 \\
0 & 0 & 0 & 0 & 1 & -\theta_{1} & 0 & -\theta_{2} \\
0 & 0 & 0 & 0 & 0 & 1 & -\theta_{3} & -\theta_{4} \\
0 & 0 & 0 & 0 & 0 & 0 & 1 & -\theta_{5} \\
0 & 0 & 0 & 0 & 0 & 0 & 0 & 1
\end{array}\right] \cdot\left[\begin{array}{c}
r_{f t} \\
r_{d, t} \\
n b r_{t} \\
r r_{t} \\
m_{t} \\
y_{t} \\
u_{t} \\
p_{t}
\end{array}\right]=\left[\begin{array}{c}
\epsilon_{t} \\
\omega_{t} \\
\lambda_{t} \\
\eta_{t} \\
\mu_{1 t} \\
\mu_{2 t} \\
\mu_{3 t} \\
\mu_{4 t}
\end{array}\right]
$$

where small letters again denote innovations.

There are a few important properties of this identification scheme that should be mentioned.

First, the reserves market variables do not directly respond to within-the-month innovations in the macro variables. This is a reasonable assumption, since neither banks nor the Fed has direct information about economic activity in the current month. Likewise, output, the unemployment rate, and the price level do not respond to within-the-month innovations in reserves market variables, which also assumes that economic agents do not react immediately to changes in these variables. Finally, the link between the reserves market and the macroeconomy is a classic money demand equation, where M2 responds to innovations in output and prices, and these innovations are transmitted to reserve market variables through reserve requirements.

As previously mentioned, this version of the model is similar to models used by Christiano and Eichenbaum, Bernanke and Blinder, and Gordon and Leeper to study the effects of monetary policy on the macroeconomy, although the implementation of monetary policy is modeled in more detail. Christiano and Eichenbaum have assumed that the supply of nonborrowed reserves is inelastic with respect to the funds rate $(\rho=\infty)$, and all of these studies have ignored the possible role of the discount ratie $\left(\beta_{2}=0\right)$. As before, these restrictions can be rejected statistically for most of the subperiods examined. In addition, the model used in this paper makes explicit the link between the 
reserves market and the macroeconomy.

Table 5 presents selected parameter estimates and variance decompositions of selected innovations using monthly VAR models of the macroeconomy. ${ }^{11}$ These estimates are entirely consistent with the previous results: Although the slope of the supply curve for nonborrowed reserves increased sharply in the $1979-82$ period, the bulk of innovations in the federal funds rate can be attributed to policy shocks. In addition, the discount rate plays an important role in determining the demand for nonborrowed reserves.

Taken together, these results indicate that the best way to uncover monetary policy shocks is to regress the federal funds rate on lags of appropriate variables that are in the Fed's information set and that presumably serve as intermediate targets or indicators of monetary policy. Furthernore, while it appears that the Fed's operational target has been fairly stable over time, no such evidence: has been presented concerning the stability of the relationship between the funds rate and the intermediate targets and indicators. That is the focus of the next section.

\section{The Fed's Intermediate Objectives}

The primary conclusion of the previous section is that innovations in the federal funds rate are good indicators of monetary policy shocks. Indeed, depending on the time period and the frequency of the data, at least 85 percent of the variance of innovations in the federal funds rate can be attributed to policy shocks. The analysis in the previous section, however, paid little attention to how those innovations were obtained. Accordingly, this section turns to estimating the Fed's intermediate policy objectives, which is tantamount to determining those variables in the Fed's reaction function that are statistically and economically important. Particular attention will be paid to whether the relationship between the federal funds rate and those variables has been stable over the past several years.

11 As before, the over-identifying restrictions can be rejected in some periods, largely biscause the model cannot account for a correlation between the unemployment rate and M2 during those periods. 
There are two different approaches that could be taken to investigate the stability of the Fed's reaction function. A more traditional approach has been to examine the statistical significance of coefficients for all variables in the reaction function. This is equivalent to estimating the response of the reaction function to a change in a particular economic variable, such as a monetary aggregate. In contrast, economists have more recently begun to examine the implications that a reaction function holds for responses to particular structural shocks rather than to specific variables. For example, one could compare the Fed's response to money demand shocks over several periods. For reasons of robustnes:; both approaches will be used to examine the stability of the Fed's intermediate policy objectives.

\section{A. Responses to Variables}

Since it has been determined that the federal funds is essentially predetermined with respect to other reserves market variables and to general macroeconomic variables, it is permissible to estimate the Fed's reaction function directly with OLS. In other words, the parameter estimates of the first equation in the reduced-form VAR model can be interpreted both as a structural (behavioral) equation and a reduced-form equation. This equation can be written as follows:

$$
R_{f, t}=\mu+\ldots+\sum_{i=1}^{p} \phi_{1 i} \cdot Y_{t-i}+\sum_{i=1}^{p} \phi_{2 i} \cdot U_{t-i}+\sum_{i=1}^{p} \phi_{3 i} \cdot P_{t-i}+\sum_{i=1}^{p} \phi_{4 i} \cdot M_{t-i}
$$

where $\mathrm{p}$ is equal to 3,6 or 12 , as previously discussed.

There is, of course, an extensive literature devoted to estimating and examining reaction functions similar to the one in equation (22). Those studies that have examined the relationship between the federal funds rate and measures of output, unemployment, prices and money are summarized in Table 6. Note that the last four columns of the table denote whether a particular study found a statistically positive response (+), a statistically-negative response (-), or an insignificant 
response $(0)$ in the federal funds rate to a change is specific variables. In general, these studies have found somewhat mixed results concerning whether the Fed responds to these variables.

There are several possible reasons why these results are not robust across studies. One important explanation for these different results is that the Fed's intermediate policy objectives have not been constant over time. As discussed in Meulendyke (1990), the Fed did not have a formal target before 1970. Although the Fed has tended to target a monetary aggregate since 1970, it has recently shifted away from using any particular variable as its primary indicator of economic activity. Moreover, even if the set of intermediate targets and indicators had remained constant, the composition of the FOMC itself has changed over time, likely resulting in a shift in the weights that the Fed has placed on any one economic variable.

Tables 7 and 8 explore whether the Fed's reaction function has been stable across various monetary regimes and across the tenures of Fed chairmen. Table 7 reports the significance of likelihood ratio (LR) tests for excluding various macroeconomic variables from the reaction function. Each row of the table corresponds to a different time period, and the last four columns of the table report the significance of LR tests for excluding the output, unemployment rate, price, and money variables, respectively. Each of the macro variables appears significantly in the reaction function when it is estimated over the full sample, as indicated in the first line of the table. This result is not robust across different subperiods, however, with respect to either monetary regimes or Fed chairmen. For the monetary regimes, only M2 appears significantly in each regime, and only the 1979-82 regime has all variables appearing significantly. Thus, it appears that much of the significance of variables for the full-sample reaction function can be traced to significance in the 1979-1982 period.

These features are fairly similar for the tests across Fed chairmen. ${ }^{12}$ The results for the

12 Hakes (1990) conducted similar tests for Fed Chairmen, although he used a constructed measure of the stance of monetary policy rather than the federal funds rate. 
Martin and Burns/Miller eras are not very different from the monetary regime results, since their tenures coincide almost exactly with the first two monetary regimes. The contrast between the Volcker and the Greenspan eras, however, are striking. First, the insignificance of coefficients in the 1982-1993 regime can be partly attributed to the Greenspan era, which is evidence to support the hypothesis that the FOMC has shifted it emphasis away from using a few specific economic indicators to guide policy toward using a variety of such indicators. Second, as with the monetary regimes, much of the significance of variables in the full-sample estimates can be attributed to the Volcker era, suggesting that the FOMC under Volcker had different intermediate objectives compared to other Fed Chairmen.

Finally, Table 8 presents the results of stability tests (Chow tests) for the FOMC's reaction function between subperiods. These results confirm those already suggested by Table 7: There is substantial evidence to suggest that the Fed's reaction function and, in particular, its intermediate objectives have experienced several structural shifts over the sample period.

\section{B. Response's to Shocks}

As discussed earlier, one can also use an estimated reaction function to examine the responses to particular structural shocks rather than to endogenous variables. While the previous approach had the advantage of determining whether a variable was statistically important in the Fed's reaction function, this second approach has the advantage of highlighting the intentions of the Fed with respect to its resporse to various shocks that buffet the macroeconomy.

Figure 1 illustrates the response of the federal funds rate to the four macroeconomic shocks in the VAR model of the macroeconomy -- a price level shock $\left(\mu_{4}\right)$, an unemployment rate shock $\left(\mu_{3}\right)$, an aggregate demand shock $\left(\mu_{2}\right)$, and a money demand shock $\left(\mu_{1}\right)$. The responses are to a one-standarddeviation shock based on the VAR model estimated over the entire sample period. Each panel plots the average response (the bold line) and $95 \%$ confidence intervals (the dotted lines). Average 
responses and confidence bounds were determined using Monte Carlo procedures with 1000 replications.

The impulse response functions can be summarized as follows. The strongest response is to unemployment rate shocks, where the funds rate is lowered three percentage points in response to a one percentage point increase in the unemployment rate. Although the funds rate is raised in response to aggregate demand shocks and to money demand shocks, the average response is only marginally significant from zero. Responses to price level shocks are very insignificant from zero.

How do these responses compare across various monetary policy regimes and different Federal Reserve Chairmen? Figures 2 and 3 graph the average responses to the same shocks as in Figure 1 but based on a VAR model estimated over the relevant time period. As shown in Figure 2, the average responses during various monetary policy regimes have the same general pattern as responses for the full-sample, although they are somewhat muted compared to the previous responsiss. Some differences do appear, however, when average responses are examined for the Fed Chairnen (Figure 3). In particular, the impulse response functions corresponding to the Volcker era stand out with stronger responses to price level shocks and to unemployment rate shocks. This feature is consistent with those results seen in Table 7, where much of the significance of variables for the full-sample reaction function can be attributable to the Volcker period.

In summary, there is significant evidence that suggests that the Fed's intermediate policy objectives have not been constant over time. This result holds whether one examines the significance of coefficients in the Fed's reaction function, or whether one looks at the responses of the Fed to various structural shocks. As a consequence, these results indicate that the Fed's reaction function should be estimated over subperiods in order to correctly identify monetary policy shock:s. In particular, the results indicate that the Volcker period should be treated separately, perhajss with an appropriate set of dummy variables. 


\section{Conclusion}

Tais paper has taken a detailed look at the implementation of monetary policy and the identification of monetary policy shocks. The paper first outlined a general analytical model for studying and evaluating monetary policy procedures. This model was used to motivate a statistical model that could be used to estimate and examine both the Fed's operational and intermediate policy objectives. The results from this exercise can be summarized as follows. First, an important conclusion of this paper is that monetary policy shocks over the past several years have primarily affected the federal funds rate, even during periods when the Fed was reportedly targeting reserves. In addition, the paper has found a statistically-significant liquidity effect in all periods examined, although it is quite small. Finally, there is statistical evidence that the Fed's intermediate objectives have not keen constant over time, and these differences appear to be economically important. Taken together, these results indicate that while monetary policy shocks can be uncovered by regressing the funds rate on variables that are in the Fed's information set, the reaction function should be estimated over subsamples rather than over the entire 1959-1993 sample period. 


\section{REFERENCES}

Abrams, Richard K., Richard Froyen, and Roger N. Waud (1980). "Monetary Policy Reaction Functions, Consistent Expectations, and the Burns Era," Journal of Money, Credit and Banking, 12:30-42.

Anderson, Richard G., and Robert H. Rasche (1982). "What Do Money Market Models Tell Us about How to Implement Monetary Policy?" Journal of Money, Credit, and Banking 14:796-828.

Barro, Robert B. (1977). "Unanticipated Money Growth and Unemployment in the United States," American Economic Review, 67(2):101-15.

Barro, Robert B. (1978). "Unanticipated Money, Output and the Price Level in the United States," Journal of Political Economy, 86(4):549-80.

Beck, Nathaniel (1982). "Presidential Influences on the Federal Reserve in the 1970's," American Journal of Political Science, 26:415-45.

Bernanke, Ben (1986). "Alternative Explanations of the Money-Income Correlation," in Rea! Business Cycles, Real Exchange Rates, and Actual Policies, Karl Brunner and Allan H. Meltzer, eds., Carnegie-Rochester Conference Series on Public Policy, 25:49-99.

Bernanke, Ben and Alan Blinder (1992). "The Federal Funds Rate and the Channels of Monetary Transmission," American Economic Review, 82:901-21.

Brunner, Allan D. (1993), "Bank Reserve Management, Reserve Requirements, and the Implementation of Monetary Policy" in Reduced Reserve Requirements: Alternatives for the Conduct of Monetary Policy and Reserve Management, Federal Reserve Bank of New York, pp. 285-330.

Brunner, Allan D. and Cara S. Lown (1993). "The Effects of Lower Reserve Requirements on Money Market Volatility," American Economic Review Papers and Proceedings, 83(2):199-2.05.

Brunner, Allan D., and Cara S. Lown (1993), "Implementing Monetary Policy with Lower Reserve Requirements," in Reduced Reserve Requirements: Alternatives for the Conduct of Monetary Policy and Reserve Management, Federal Reserve Bank of New York, pp. 249-284.

Christiano, Lawrence J. and Martin Eichenbaum (1992), "Identification and the Liquidity Effects of a Monetary Shock," in A. Cuikerman, L. Z. Hercowitz, and L. Leiderman, eds., Business Cycles, Growth and Political Economy, Cambridge, MA: MIT Press.

DeRosa, Paul, and Gary H. Stern (1977). "Monetary Control and the Federal Funds Rate," Journal of Monetary Economics, 3:217-30.

Dewald, William G., and Harry G. Johnson (1963). "An Objective Analysis of the Objectives of American Monetary Policy," in Banking and Monetary Studies, edited by D. Carson, pp. 171- 
89, Homewood, IL: Richard D. Irwin.

Epstein, Gerrald A., and Juliet B. Schor (1986). "The Political Economy of Central Banking," manuscript, Harvard Institute for Economic Research.

Esaki, Howard Y. (1981). "Interest Rates, Short-run Monetary Policy, and the Federal Reserve Reaction Function," Ph.D. dissertation, Yale University.

Feinman, Joshua (1993). "Estimating the Open Market Desk's Daily Reaction Function," Journal of Money, Credit, and Banking, 25:231-247.

Gordon, David B. and Eric M. Leeper (1993). "The Dynamic Impacts of Monetary Policy: An Exercise in Tentative Identification," Federal Reserve Bank of Atlanta Working Paper Series, Working Paper 93-5.

Hakes, David R. (1990). "The Objectives and Priorities of Monetary Policy under Different Federal Res:erve Chairmen," Journal of Money, Credit and Banking, 22(3):327-337.

Havrilesky, Thomas P., Robert Sapp, and Robert Schweitzer (1975). "Tests of the Federal Reserve's Reaction to the State of the Economy: 1964-1974," Social Science Quarterly, 55:835-52.

Khoury, Salwa S. (198 ). "The Federal Reserve Reaction Function: A Specification Search," in Thomas Mayer, ed., The Political Economy of American Monetary Policy, Cambridge, England: Cambridge University Press, 27-41.

Leeper, Eric M. and David B. Gordon (1992). "In Search of the Liquidity Effect," Journal of Monetary Economics, 29:341-69.

Lombra, Raymond, and Michael Moran (1980). "Policy Advice and Policymaking at the Federal Reserve," Carnegie-Rochester Conference Series on Public Policy, 13:9-68.

McCallum, B. T. (1990), "Targets, Indicators, and Instruments of Monetary Policy," Monetary Policy in an Era of Change, Washington, D.C.: American Enterprise Institute.

McNees, Stephen K. (1986). "Modeling the Fed: A Forward-Looking Monetary Policy Reaction Function," New England Economic Review, November-December:3-8.

Meulendyke, Ann-Marie (1990). "A Review of Federal Reserve Policy Targets and Operating Guides in Recent Decades," in Intermediate Targets and Indicators for Monetary Policy, Federal Reserve Bank of New York, pp. 452-473.

Sheehan, Robert G. (1985). "The Federal Reserve Reaction Function: Does Debt Growth Influence Monetary Policy," Federal Reserve Bank of St. Louis Review, 67(3):24-33. 
Sims, Christopher A. (1972). "Money, Income, and Causality," American Economic Review, 62:540-52.

Sims, Christopher A. (1980). "Macroeconomics and Reality," Econometrica, 48:1-48.

Sims, Christopher A. (1986). "Are Forecasting Models Usable for Policy Analysis?" Quarteriy Review, Federal Reserve Bank of Minneapolis, Winter:2-16.

Strongin, Steven (1992). "The Identification of Monetary Policy Disturbances: Explaining the Liquidity Puzzle," Federal Reserve Bank of Chicago Working Paper Series, Working Paper 9227.

Tinsley, P., et. al, (1982), "Policy Robustness: Specification and Simulation of a Monthly Money Market Model," Journal of Money, Credit, and Banking 14, No. 4 Part 2 (November): 829-56.

Witte, Willard E. (1984). "Cyclical Variation in the Short-run Federal Reserve Reaction Function, 1969-1978," Journal of Macroeconomics, 6(4):457-64. 


\section{APPENDIX}

\section{A Review of Monetary Policy Procedures}

Although the ultimate goals of U.S. monetary policy -- sustainable economic growth and price stability -- have remained largely unchanged over the past several years, the technical aspects of how these goals have been implemented have shifted dramatically. This section of the paper reviews the history of monetary policy procedures at the Federal Reserve since the 1950 s and follows closely the discussion in Meulendyke (1990). These policy procedures are summarized briefly in Table 1.

1959 to 1969. After the Treasury-Federal Reserve Accord in 1951, the Federal Reserve resumed its pursuit of its monetary policy goals. Those goals had been put aside during World War II in order to promote low interest rates on Treasury securities. During the 1950s, the Fed developed open market operations into the primary tool for implementing short-run policy objectives. The discount rate and reserve requirements were adjusted only occasionally: The discount rate was changed when the rate became out of line with other short-term market rates, and both instruments were sometimes used to signal the extent of policy shifts.

Although the FOMC did not have formal intermediate targets during this period, it monitored several indicators of economic activity. It paid particular attention to bank credit -- seeking to stimulate bank lending when overall economic activity was flagging and to slow it down when economic activity appeared to be too robust.

Operationally, the Federal Reserve targeted free reserves, with targets implied by the discussion at the most recent FOMC meeting. Since the Fed's forecasts of free reserves were subject to large errors (primarily because of the unpredictability of excess reserves), the Trading Desk at the Federal Reserve Bank of New York closely monitored daily conditions in the money market. In particular, the Desk watched movements in Treasury bill rates and other short-term market rates. The federal funds rate was not initially viewed as an important indicator of reserve availability, since the 
interbank markets were fairly thin. But the funds rate received increasingly more attention as the market began to grow in the $1960 \mathrm{~s}$.

During the late 1960s, the Federal Reserve and others began to question the current policy procedures. Some economists, for example, suggested that the Fed should pay more attention to money growth, while others pointed to using the monetary base or total reserves as intermediate indicators. In response, the FOMC added money growth and total reserves to the list of intermediate indicators. With respect to operational targets, free reserves remained the primary objective, a though the Desk began to rely more heavily on the level of borrowed reserves, as the excess reserves component of free reserves continued to be difficult to predict.

1970 to 1979 . In 1970 , the Federal Reserve formally adopted monetary targets with the intention of using them to combat inflation. Bank credit remained in the list of indicators, but it received increasingly less attention. Initially, the FOMC used weekly tracking paths for M1. These were replaced in 1972 with two-month growth rate ranges, which were further supplemented in 1978, in accordance with the Humphrey-Hawkins Act, with annual growth rate ranges.

Also in 1970, the federal funds rate became the primary operational target. A target rate was chosen to be consistent with current reserve estimates and the desired growth rate of $\mathrm{M} 1$, and the FOMC voted on a range surrounding the target rate that put limits on the target adjustments that the Desk could make between FOMC meetings.

1979 to 1982 . In October 1979, the Federal Reserve moved to targeting nonborrowed reserves in order to achieve its intermediate objectives. Operationally, the Federal Reserve chose a levil of total reserves consistent with the desired growth rates for M1 and M2. In turn, using models ior money demand and borrowed reserves, the Fed calculated the implied target level for nonborrowed reserves and an expected federal funds rate. These targets were adjusted weekly, using new information on currency, deposits, and reserves. Although the role of the federal funds rate was diminished during 
this period. it continued to be used as a short-run indicator of the accuracy of reserve forecasts.

1982 to the Present. By late 1982, it was evident that the relationship between M1, M2 and economic activity was breaking down, primarily because of the deregulation of interest rates on various types of deposits, particularly on NOW and money market deposit accounts. Initially, it was hoped that this disruption would be short-lived. In response to these developments, the Federal Reserve made several ad hoc adjustments to its policy procedures. First, the role of money growth as an intermediate target was deemphasized, and inflation, measures of economic activity and foreign exchange developments received greater attention.

In addition, the Fed moved to choosing the borrowing level directly. The Desk continued to use the fecleral funds rate as a guide for making daily adjustments to nonborrowed reserves. Indeed, as the 198 Js progressed, the relationship between borrowed reserves, the discount rate and the federal funds rate became more uncertain and the Desk increasingly relied on the federal funds rate as a shortrun indicalor of reserve availability. 
Table 1. Operational and Intermediate Objectives of the Federal Reserve, 1959-Present

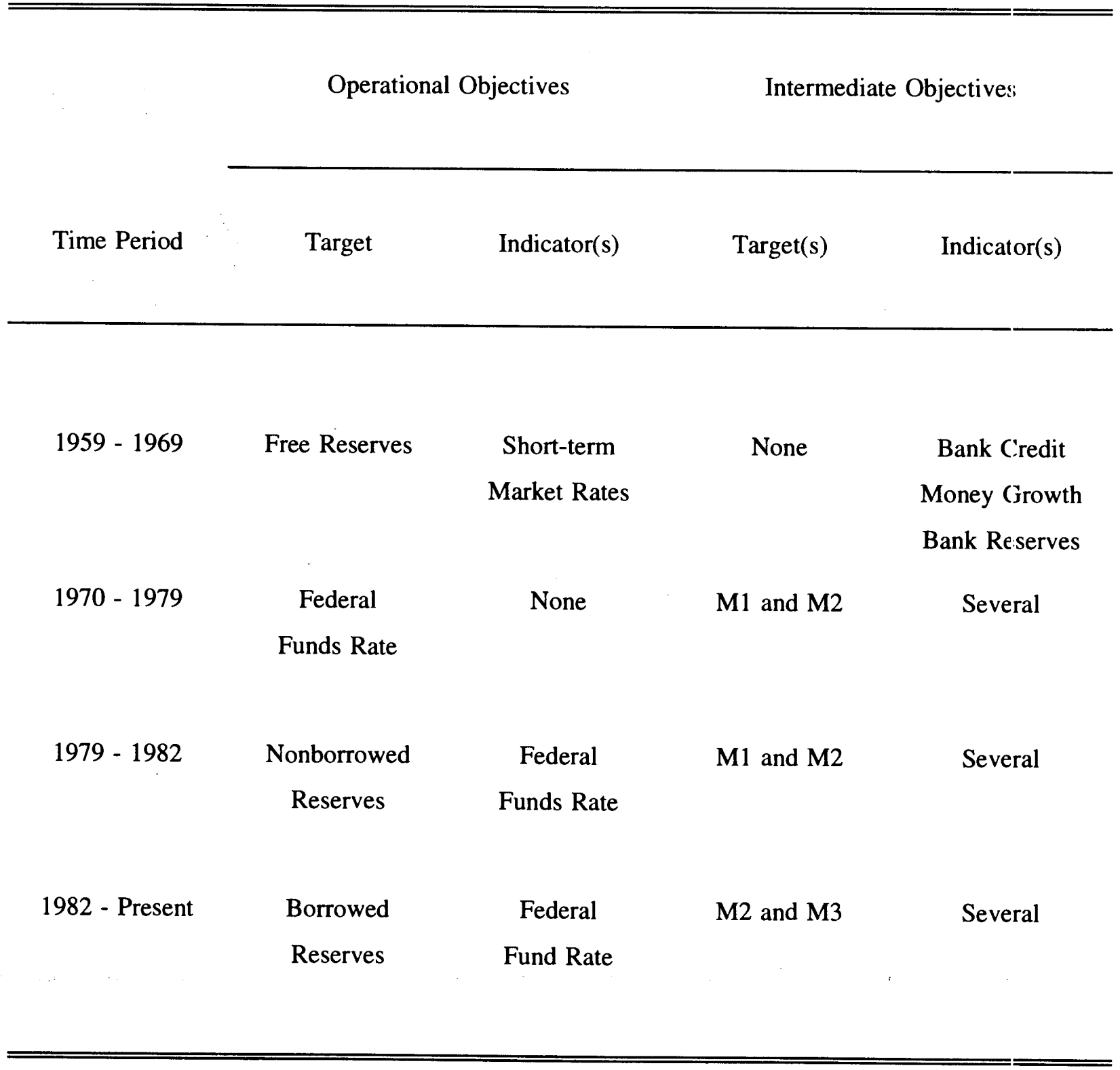


Table 2. Summary of Monthly VAR Models of the Reserves Market, 1959-1993

\begin{tabular}{|c|c|c|c|c|}
\hline \multirow[b]{2}{*}{$\underline{\text { Parameter Estimates }}$} & \multirow[t]{2}{*}{$1959-1969$} & \multirow[t]{2}{*}{$1970-1979$} & \multirow[t]{2}{*}{$1979-1982$} & \multirow[t]{2}{*}{$1982-199 ?$} \\
\hline & & & & \\
\hline \multirow[t]{2}{*}{$\rho$} & .004 & .006 & .231 & .005 \\
\hline & $(.018)$ & $(.017)$ & $(.114)$ & $(.007)$ \\
\hline \multirow[t]{2}{*}{$\pi$} & .115 & .175 & .180 & .306 \\
\hline & $(.037)$ & $(.037)$ & $(.044)$ & $(.040)$ \\
\hline \multirow[t]{2}{*}{$\beta_{1}$} & -.768 & -.976 & -.357 & -.719 \\
\hline & $(.118)$ & (.199) & $(.157)$ & $(.320)$ \\
\hline \multirow[t]{2}{*}{$\beta_{2}$} & .972 & .898 & .710 & -.120 \\
\hline & $(.270)$ & $(.443)$ & $(.405)$ & $(.576)$ \\
\hline \multirow[t]{2}{*}{$\beta_{3}$} & .977 & 1.042 & .966 & .965 \\
\hline & $(.022)$ & $(.035)$ & $(.078)$ & $(.021)$ \\
\hline \multirow[t]{2}{*}{$\beta_{4}$} & .071 & .436 & .015 & .126 \\
\hline & $(.196)$ & $(.308)$ & $(.774)$ & $(.308)$ \\
\hline \multirow[t]{2}{*}{$\alpha$} & -.368 & 1.382 & 4.075 & 2.344 \\
\hline & $(.801)$ & $(.791)$ & $(1.440)$ & $(1.257)$ \\
\hline \multicolumn{5}{|c|}{ Contribution of Policy Shocks to Variance of: } \\
\hline$N_{B R}-E_{t-1} N B R_{t}$ & 2 & 2 & 7 & 0 \\
\hline$R_{f, t}-E_{t-1} R_{f, t}$ & 100 & 100 & 86 & 100 \\
\hline
\end{tabular}


Table 3. Summary of Weekly VAR Models of the Reserves Market, 1959-1993

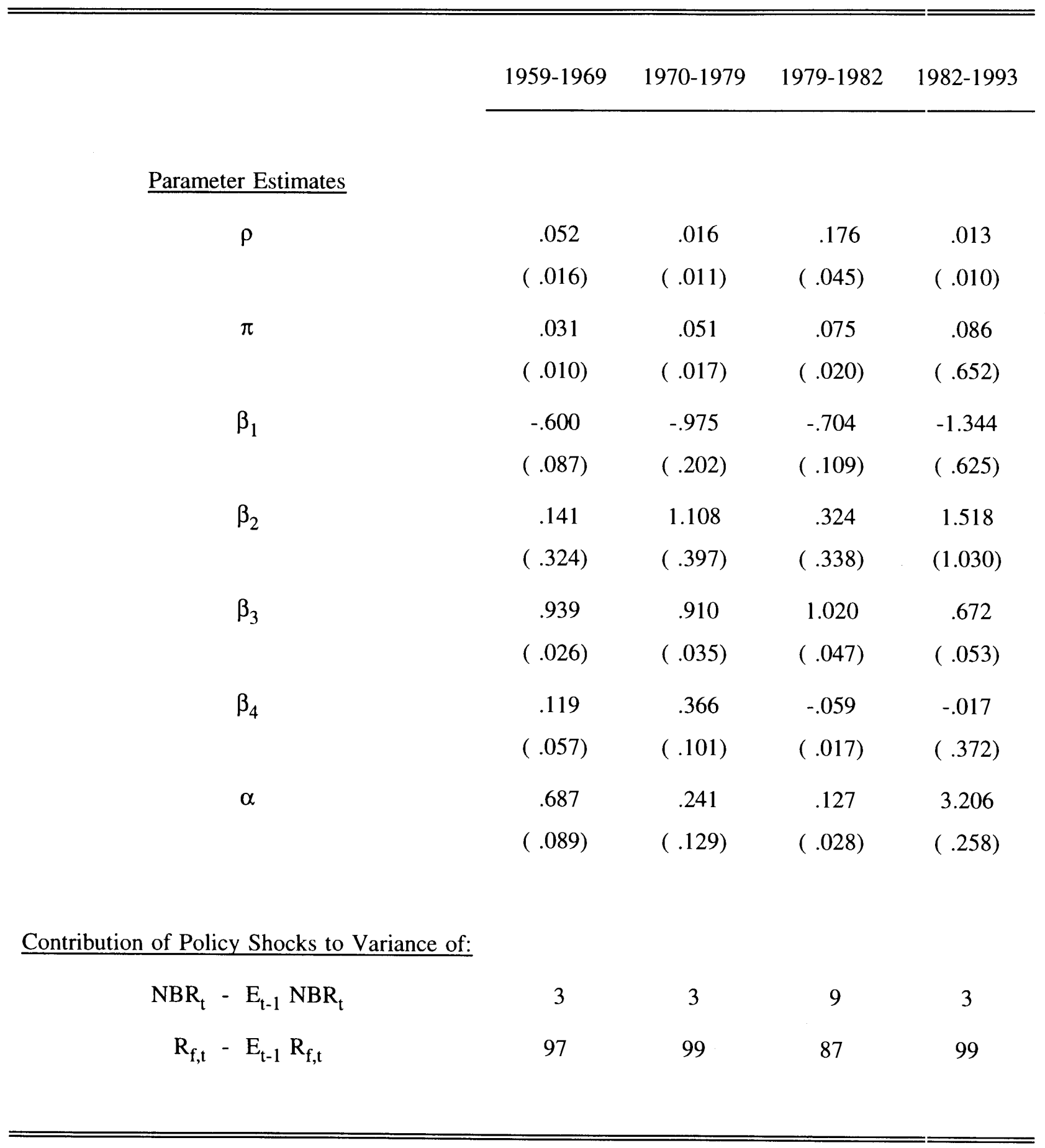


Table 4. Summary of Weekly VAR Models of the Reserves Market, 1982-1993

\begin{tabular}{|c|c|c|c|}
\hline & $1982-1993$ & 1984-1993 & 1988-1993 \\
\hline \multicolumn{4}{|l|}{$\underline{\text { Parameter Estimates }}$} \\
\hline \multirow[t]{2}{*}{$\rho$} & .013 & .023 & .006 \\
\hline & $(.010)$ & $(.012)$ & $(.006)$ \\
\hline \multirow[t]{2}{*}{$\pi$} & .086 & .093 & .223 \\
\hline & $(.013)$ & $(.015)$ & $(.037)$ \\
\hline \multirow[t]{2}{*}{$\beta_{1}$} & -1.344 & -1.967 & -3.092 \\
\hline & $(.625)$ & $(.793)$ & (1.364) \\
\hline \multirow[t]{2}{*}{$\beta_{2}$} & 1.518 & 1.487 & -.714 \\
\hline & (1.030) & (1.114) & $(1.250)$ \\
\hline \multirow[t]{2}{*}{$\beta_{3}$} & .672 & .628 & .593 \\
\hline & $(.053)$ & $(.071)$ & $(.069)$ \\
\hline \multirow[t]{2}{*}{$\beta_{4}$} & -.017 & .142 & 1.381 \\
\hline & $(.372)$ & $(.463)$ & $(.520)$ \\
\hline \multirow[t]{2}{*}{$\alpha$} & 3.206 & 3.986 & 4.348 \\
\hline & $(.258)$ & $(.237)$ & $(.356)$ \\
\hline \multicolumn{4}{|c|}{ Contribution of Policy Shocks to Variance of: } \\
\hline$N_{B R}-E_{t-1} N_{t} R_{t}$ & 3 & 5 & 4 \\
\hline$R_{f, t}-E_{t-1} R_{f, t}$ & 99 & 96 & 99 \\
\hline
\end{tabular}


Table 5. Summary of Monthly VAR Models of the Macroeconomy, 1959-1993

\begin{tabular}{|c|c|c|c|c|}
\hline & $1959-1969$ & $1970-1979$ & 1979-1982 & $1982-1993$ \\
\hline \multicolumn{5}{|l|}{$\underline{\text { Parameter Estimates }}$} \\
\hline \multirow[t]{2}{*}{$\rho$} & -.008 & .003 & .126 & .008 \\
\hline & $(.018)$ & $(.015)$ & $(.066)$ & $(.008)$ \\
\hline \multirow[t]{2}{*}{$\pi$} & .089 & .218 & .119 & .263 \\
\hline & $(.038)$ & $(.039)$ & $(.062)$ & $(.040)$ \\
\hline \multirow[t]{2}{*}{$\beta_{1}$} & -.729 & -.753 & -1.111 & -.723 \\
\hline & $(.115)$ & $(.215)$ & $(.128)$ & $(.320)$ \\
\hline \multirow[t]{2}{*}{$\beta_{2}$} & .937 & 1.116 & .661 & .121 \\
\hline & $(.255)$ & $(.445)$ & $(.406)$ & (.599) \\
\hline \multirow[t]{2}{*}{$\beta_{3}$} & .947 & 1.046 & 1.283 & .948 \\
\hline & $(.022)$ & $(.032)$ & $(.070)$ & $(.023)$ \\
\hline \multirow[t]{2}{*}{$\beta_{4}$} & -.019 & .831 & -2.253 & -.112 \\
\hline & $(.203)$ & $(.325)$ & $(.441)$ & $(.320)$ \\
\hline \multirow[t]{2}{*}{$\alpha$} & .015 & 1.504 & 1.378 & .620 \\
\hline & $(.831)$ & $(.926)$ & (1.359) & $(1.242)$ \\
\hline \multicolumn{5}{|c|}{ Contribution of Policy Shocks to Variance of: } \\
\hline$N_{B R}-E_{t-1} N_{t} R_{t}$ & 2 & 1 & 13 & 0 \\
\hline$R_{f, t}-E_{t-1} R_{f, t}$ & 99 & 100 & 99 & 99 \\
\hline
\end{tabular}


Table 6. Previous Estimates of the FOMC Policy Rule

Using the Federal Funds Rate as the Operational Target

\begin{tabular}{|c|c|c|c|c|c|c|}
\hline \multirow[b]{2}{*}{ Study } & \multirow[b]{2}{*}{ Period } & \multirow[b]{2}{*}{ Freq. } & \multicolumn{4}{|c|}{ Change in FF Rate in Response to Increase in: } \\
\hline & & & Output & Unemployment & Prices & Money \\
\hline $\begin{array}{l}\text { Havriesky } \\
\text { et al. }\end{array}$ & $\begin{array}{c}1964-66 \\
1966-68 \\
1967-70 \\
1970-71 \\
1971-72 \\
1972-74\end{array}$ & M & & $\begin{array}{l}0 \\
- \\
0 \\
- \\
0 \\
-\end{array}$ & $\begin{array}{l}+ \\
+ \\
+ \\
- \\
+ \\
+\end{array}$ & \\
\hline $\begin{array}{l}\text { DeRosa } \\
\text { and Stern }\end{array}$ & $\begin{array}{l}1967-69 \\
1970-74\end{array}$ & M & $\begin{array}{l}0 \\
+\end{array}$ & & & $\begin{array}{l}0 \\
+\end{array}$ \\
\hline $\begin{array}{l}\text { Abráms } \\
\text { et al. }\end{array}$ & $1970-77$ & M & & - & + & + \\
\hline $\begin{array}{l}\text { Lombra } \\
\text { and Nloren }\end{array}$ & $1971-73$ & $\mathrm{Q}$ & + & & + & + \\
\hline Esaki & $1974-79$ & M & & - & 0 & \\
\hline Beck & $\begin{array}{l}1970-79 \\
1970-74\end{array}$ & M & & $\begin{array}{l}0 \\
0\end{array}$ & $\begin{array}{l}+ \\
+\end{array}$ & \\
\hline Wilte & $1969-78$ & M & + & & + & + \\
\hline Sheehan & $\begin{array}{l}1958-84 \\
1958-83\end{array}$ & Q & & - & $\begin{array}{l}0 \\
0\end{array}$ & \\
\hline $\begin{array}{l}\text { Epstein } \\
\text { and Schor }\end{array}$ & $1966-83$ & Q & + & & + & \\
\hline McNees & $\begin{array}{l}1970-86 \\
1970-86\end{array}$ & $\mathrm{Q}$ & 0 & - & 0 & $\begin{array}{l}+ \\
+\end{array}$ \\
\hline
\end{tabular}


Table 7. Tests for Exclusion of Selected Intermediate Targets and Indicators in the Federal Reserve's Reaction Function

\begin{tabular}{|c|c|c|c|c|c|}
\hline \multirow[b]{2}{*}{ Time Period } & \multirow[b]{2}{*}{$\begin{array}{l}\text { Number } \\
\text { of lags (p) }\end{array}$} & \multicolumn{4}{|c|}{ Significance of LR Test for the Exclusion of: } \\
\hline & & Output & Unemployment & Prices & Money \\
\hline $\begin{array}{c}1 / 59-6 / 93 \\
\text { (Entire Sample) }\end{array}$ & 12 & .01 & $<.01$ & .01 & .01 \\
\hline \multicolumn{6}{|l|}{ Monetary Regimes } \\
\hline $1 / 59-12 / 69$ & 6 & .05 & .45 & .15 & .11 \\
\hline $1 / 70-9 / 79$ & 6 & .17 & .06 & .65 & $<.01$ \\
\hline $10 / 79-10 / 82$ & 3 & .11 & $<.01$ & $<.01$ & $<.01$ \\
\hline $11 / 82-6 / 93$ & 6 & .29 & .27 & .67 & .04 \\
\hline \multicolumn{6}{|l|}{$\underline{\text { Fed Chairmen }}$} \\
\hline $\begin{array}{c}1 / 59-1 / 70 \\
\text { (Martin) }\end{array}$ & 6 & .04 & .42 & .12 & .10 \\
\hline $\begin{array}{c}2 / 70-7 / 79 \\
\text { (Burns/Miller) }\end{array}$ & 6 & .17 & .14 & .67 & $<.01$ \\
\hline $\begin{array}{c}8 / 79-8 / 87 \\
\text { (Volcker) }\end{array}$ & 6 & $<.01$ & .03 & $<.01$ & $<.01$ \\
\hline $\begin{array}{l}9 / 87-6 / 93 \\
\text { (Greenspan) }\end{array}$ & 6 & .11 & .01 & .98 & .62 \\
\hline
\end{tabular}


Table 8. Tests for Structural Stability of the Federal Reserve's Reaction Function

\begin{tabular}{ccc}
\hline \hline Test of Structural Break Between: & $\begin{array}{c}\text { Value of } \\
\text { F-statistic }\end{array}$ & $\begin{array}{c}\text { Significance } \\
\text { of F-statistic }\end{array}$ \\
\hline Monetary Regimes & & \\
$1 / 59-12 / 69$ and $1 / 70-9 / 79$ & 2.17 & $<.01$ \\
$1 / 70-9 / 79$ and $10 / 79-10 / 82$ & 7.77 & $<.01$ \\
$10 / 79-10 / 82$ and $11 / 92-6 / 93$ & 11.22 & $<.01$ \\
Fed Chairmen & & $<.01$ \\
Martin and Burns/Miller & & $<.01$ \\
Burns/Miller and Volcker & 2.16 & .30 \\
Volcker and Greenspan & 2.17 & \\
\hline \hline
\end{tabular}


Figure 1. Response of Federal Funds Rate to Selected Shocks

(based on VAR model of macroeconomy using full sample)
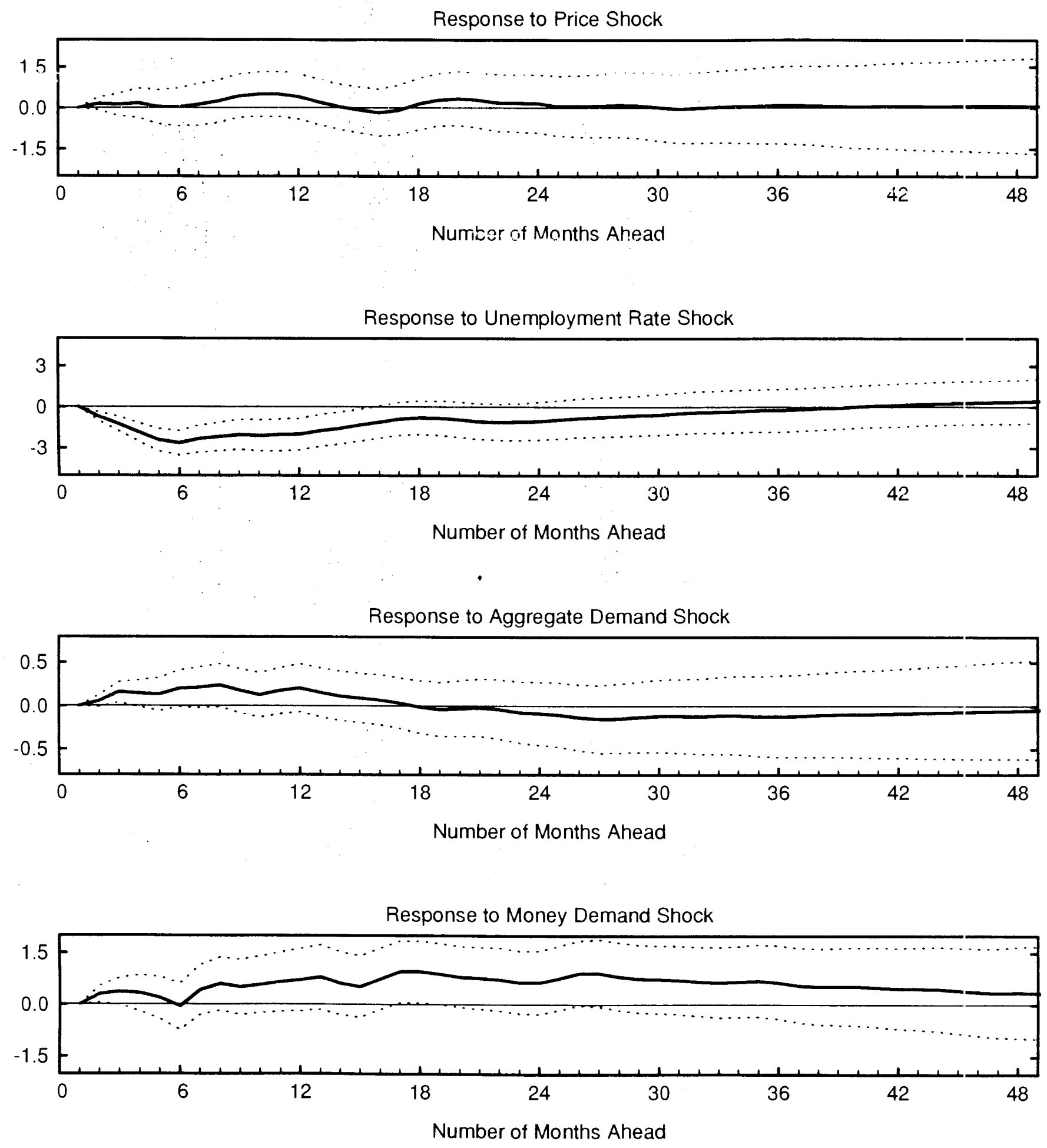
Figure 2. Response of Federal Funds Rate Under Various Monetary Regimes $(1959-1969=$ , 1970-1979=., $1979-1982=\ldots \cdot-., 1982-1993=\ldots \ldots$ )

Response to Price Shock

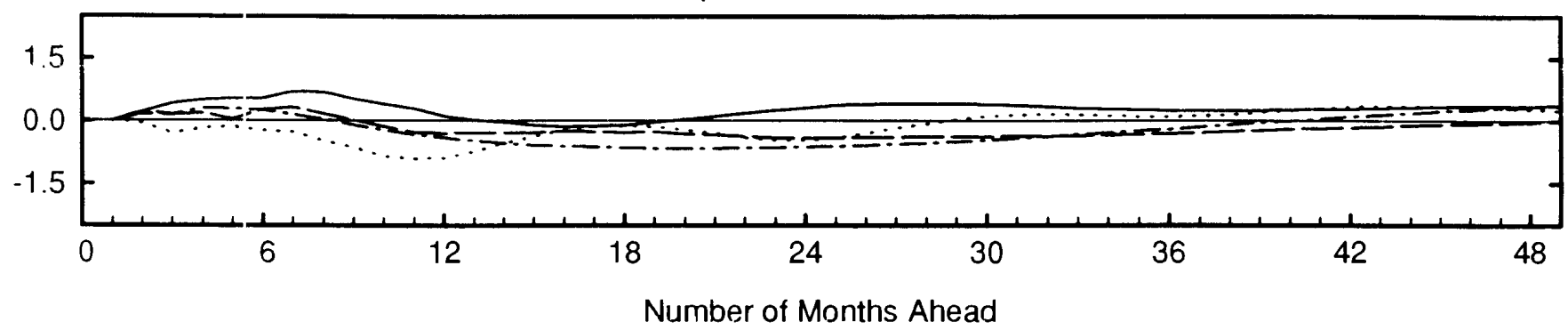

Response to Unemployment Rate Shock

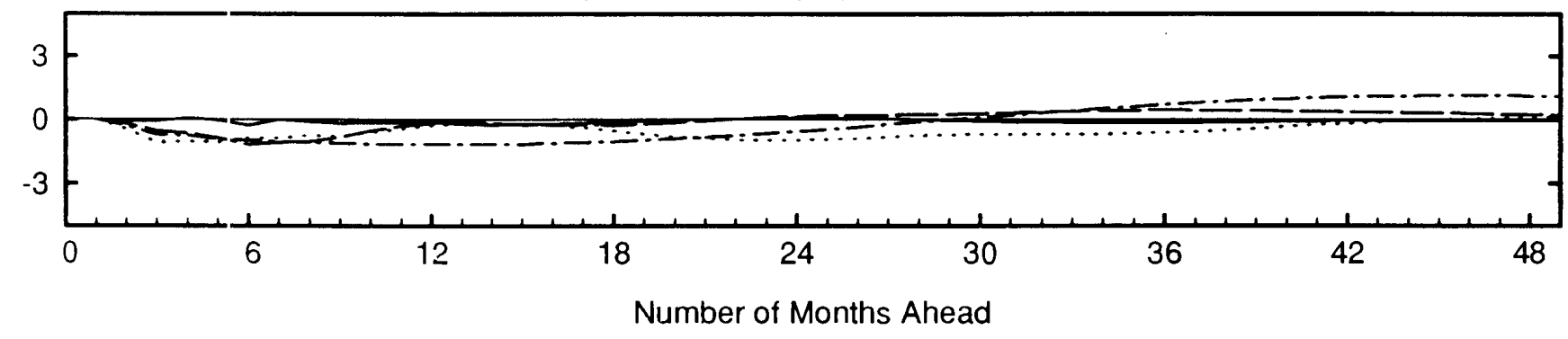

Response to Aggregate Demand Shock

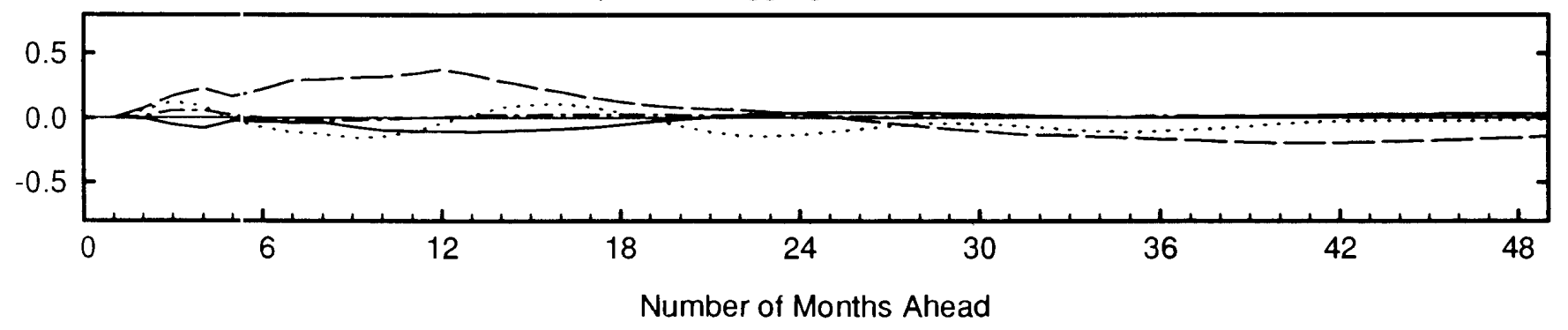

Response to Money Demand Shock

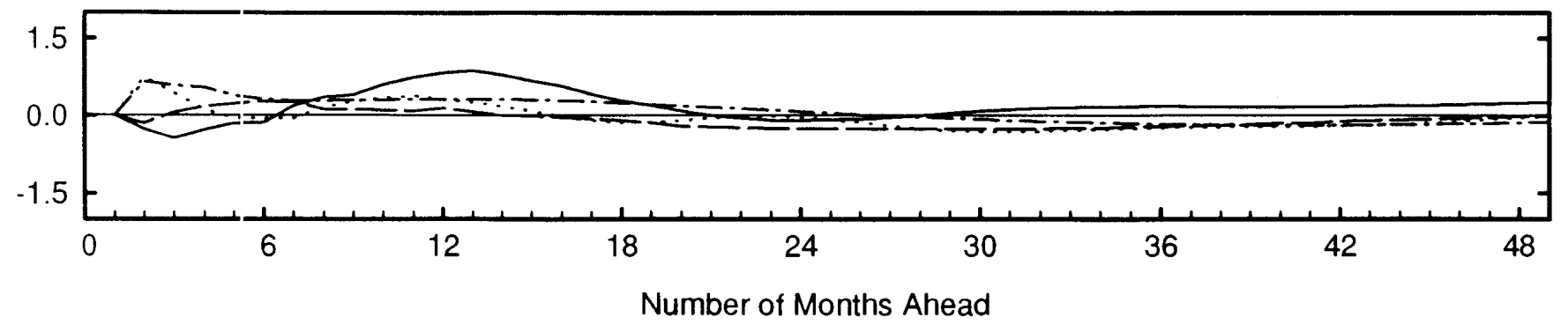


Figure 3. Response of Federal Funds Rate Under Various Fed Chairm ən (Martin=

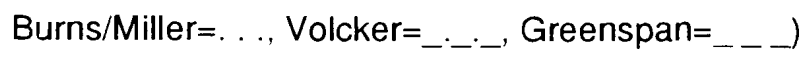
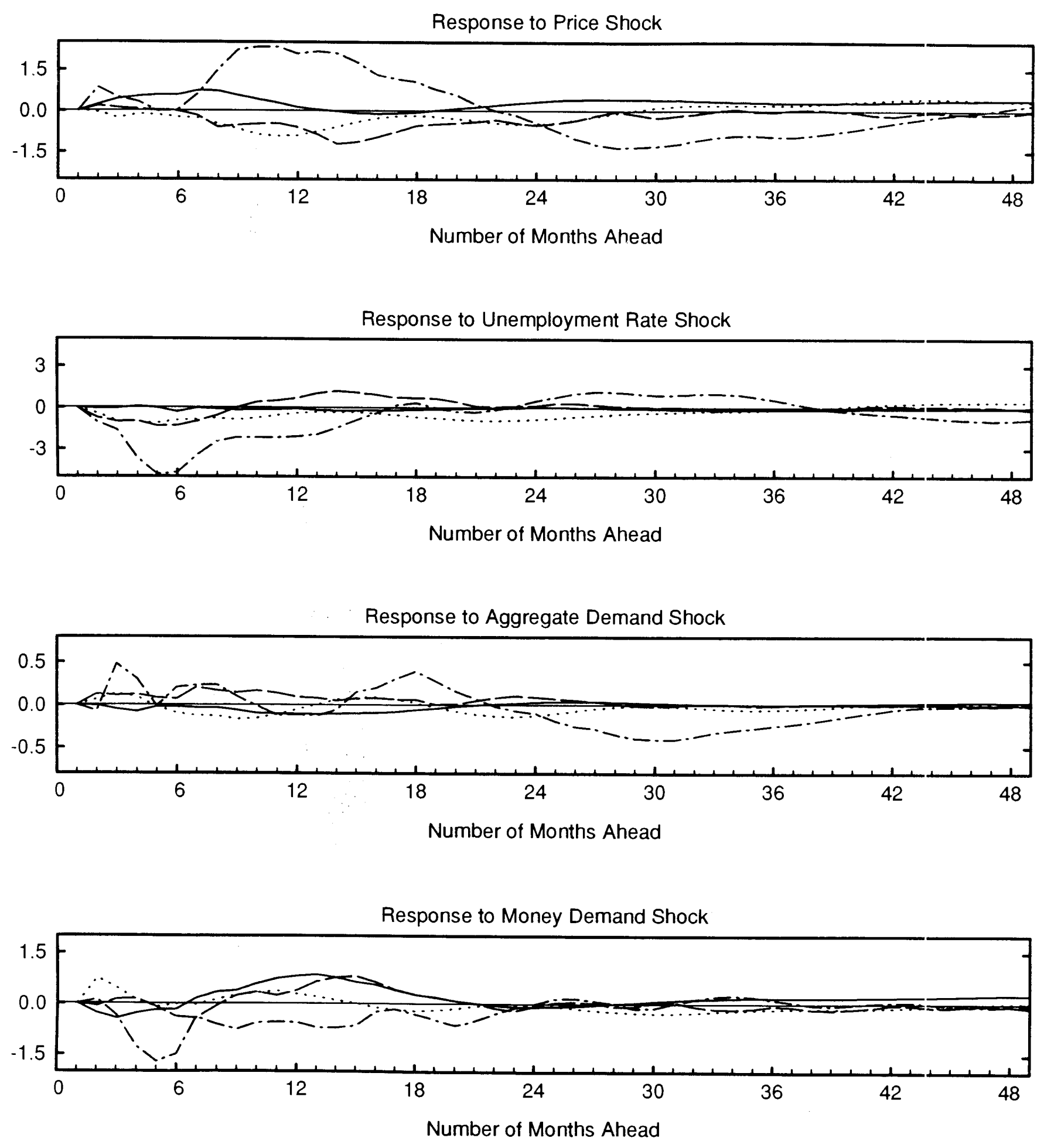


\section{International Finance Discussion Papers}

IFDP

Number

466

465 Understanding the Empirical Literature on Purchasing Power Parity: The Post-Bretton Woods Era

464 Inflation, Inflation Risk, and Stock Returns

463 Are Apparent Productive Spillovers a Figment of Specification Error?

462 When do long-run identifying restrictions give reliable results?

\section{$\underline{1993}$}

$461 \quad$ Fluctuating Confidence and Stock-Market Returns

460 Dollarization in Argentina

459 Union Behavior, Industry Rents, and Optimal Policies

458 A Comparison of Some Basic Monetary Policy Regimes: Implications of Different Degrees of Instrument Adjustment and Wage Persistence

457 Cointegration, Seasonality, Encompassing, and the Demand for Money in the United Kingdom

456

455
Exchange Rates, Prices, and External Adjustment in the United States and Japan

Political and Economic Consequences of Alternative Privatization Strategies

Is There a World Real Interest Rate?
Allan D. Brunner

Hali J. Edison Joseph E. Gagnon William R. Melick

John Ammer

Susanto Basu John S. Fernald

Jon Faust Eric M. Leeper

Alexander David

Steven B. Kamin

Neil R. Ericsson

Phillip Swagel

Dale W. Henderson

Warwick J. McKibbin

Neil R. Ericsson

David F. Hendry

Hong-Anh Tran

Peter Hooper Jaime Marquez

Catherine L. Mann

Stefanie Lenway

Derek Utter

Joseph E. Gagnon

Mark D. Unferth

Please address requests for copies to International Finance Discussion Papers, Division of International Finance, Stop 24, Board of Governors of the Federal Reserve System, Washingtorı, D.C. 20551. 


\section{International Finance Discussion Papers}

IFDP

Number

$\underline{\text { Titles }}$

Author(s)

1993

453 Macroeconomic Stabilization Through Monetary and Fiscal Policy Coordination Implications for Monetary Union

452 Long-term Banking Relationships in General Equilibrium

Jay H. Bryson

The Role of Fiscal Policy in an Incomplete

Markets Framework

Charles P. Thomas

450 Internal Funds and the Investment Function

$449 \quad$ Measuring International Economic Linkage with Stock Data

Michael S. Gibson

Guy V.G. Stevens

John Ammer

Jianping Mei

448 Macroeconomic Risk and Asset Pricing: Estimating the APT with Observable Factors

John Ammer

447 Near observational equivalence and unit root processes: formal concepts and implications

Jon Faust

$446 \quad$ Market Share and Exchange Rate Pass-Through in World Automobile Trade

Robert C. Feenstra Joseph E. Gagnon

Michael M. Knetter

445 Industry Restructuring and Export Performance: Evidence on the Transition in Hungary

Valerie J. Chang

Catherine I. Mann

Guy V.G. Sitevens A Note

443 Global versus Country-Specific Productivity Shocks and the Current Account

Reuven Glick Kenneth Rogoff

442 The GATT's Contribution to Economic Recovery in Post-War Western Europe

Douglas A. Irwin

441 A Utility Based Comparison of Some Models of Exchange Rate Volatility

Kenneth D. West

Hali J. Edison

Dongchul Cho

Cointegration Tests in the Presence of Structural Breaks

Julia Campos

Neil R. Ericsson

David F. Hendry 